\title{
PERMAINAN BOLA KECIL UNTUK MENINGKATKAN KETERAMPILAN MOTORIK KASAR ANAK USIA DINI PADA KELOMPOK B DI TK PERTIWI DWP KOTA TASIKMALAYA
}

\author{
Lutfi Nur ${ }^{1}$, Edi Hendri Mulyana ${ }^{2}$, Muhammad Azhar Perdana ${ }^{3}$ \\ ${ }^{1}$ Program Studi PGPAUD UPI Kampus Tasikmalaya \\ ${ }^{2}$ Program Studi PGPAUD UPI Kampus Tasikmalaya \\ ${ }^{3}$ Program Studi PGPAUD UPI Kampus Tasikmalaya \\ Email: lutfinur@upi.edu
}

(Received: Mei 2017; Accepted: Mei 2017; Published: Juni 2017)

\begin{abstract}
Gross motor development is one that needs to be considered by all parties, especially the elderly because of its urgency in the growth of early child development. Gross motor development when inhibited will affect the achievement of child maturity. Gross motor development is divided into 3 aspects namely Lokomotor basic motion, basic motion Non Lokomotor, and Manipulative basic motion. Problems found in Group B in TK Pertiwi DWP Tasikmalaya City still low Motorik Crude Child skills caused by learning that is still conventional that less touched the motor directly. This is shown from the observation of the achievement of gross motor skills as much as $0-2$ children $(0 \%-14.28 \%)$. One way to improve Gross motor skills of early childhood Gross small ball games. The result of Gross Motor Skill Study in Group B in TK Pertiwi DWP Tasikmalaya showed that in cycle I, there was an increase of 3 - 5 children $(21.42 \%$ - 35.71\%). Cycle II action after reflection increased the achievement of the number of children for each indicator as much as $6-8$ children $(42.85 \%-57.14 \%)$. In the third cycle action there was an increase showing that as many as $10-12$ children $(71.42 \%-85.71 \%)$ for each indicator. So with the results of small ball game research is considered successful able to improve the Gross motor skills of children in group B TK Pertiwi DWP Kota Tasikmalaya.
\end{abstract}

Keywords: Early Childhood, Gross Motor Skill, Small Ball Game.

\begin{abstract}
ABSTRAK
Perkembangan motorik kasar merupakan salah satu yang perlu diperhatikan oleh semua pihak khususnya orang tua karena urgensinya dalam tumbuh kembang anak usia dini.Perkembangan motorik kasar ketika terhambat akan mempengaruhi terhadap pencapaian kematangan anak. Perkembangan motorik kasar terbagi menjadi 3 aspek yaitu gerak dasar Lokomotor, gerak dasar Non Lokomotor, dan gerak dasar Manipulatif. Masalah yang ditemukan pada Kelompok B di TK Pertiwi DWP Kota Tasikmalaya masih rendahnya keterampilan Motorik Kasar Anak yang disebabkan pembelajaran yang masih konvensional yang kurang menyentuh motorik secara langsung . Hal tersebut ditunjukan dari hasil observasi pencapaian keterampilan motorik kasar sebanyak $0-2$ anak $(0 \%-14,28 \%)$. Salah satu cara untuk meningkatkan keterampilan motorik kasar anak usia dini melalui permainan bola kecil. Hasil penelitian Keterampilan Motorik Kasar pada kelompok B di TK Pertiwi DWP Kota Tasikmalaya menunjukan pada tindakan siklus I terjadi peningkatan sebanyak $3-5$ anak $(21,42 \%-35,71 \%)$. Tindakan Siklus II setelah melakukan refleksi terjadi peningkatan pencapaian jumlah anak untuk setiap indikatornya sebanyak $6-8$ anak $(42,85 \%-57,14 \%)$. Pada tindakan siklus III terjadi peningkatan yang menunjukan bahwa sebanyak 10 - 12 anak $(71,42 \%$ - 85,71\%) untuk setiap indikatornya. Sehingga dengan hasil tersebut penelitian permainan bola kecil dianggap berhasil mampu meningkatkan keterampilan motorik kasar anak pada kelompok B TK Pertiwi DWP Kota Tasikmalaya.
\end{abstract}

Kata Kunci : Anak Usia Dini, Keterampilan Motorik Kasar, Permainan Bola Kecil 


\section{PENDAHULUAN}

Rentang usia sejak dilahirkan sampai usia 6 tahun ini adalah usia yang sangat menetukan pembentukan karakter, kepribadian dan sedang menjalani suatu proses perkembangan dengan pesat dan fundamental bagi kehidupan selanjutnya (Sujiono,2009,hlm. 6). Pada Masa ini sering dikenal sebagai masa keemasan anak (golden age) bagi anak karena berbagai aspek pertumbuhan dan perkembangan telah mengalami masa yang cepat dalam rentang perkembangan manusia. Makanan yang bergizi seimbang dan stimulasi yang intensif sangat dibutuhkan untuk pertumbuhan dan perkembangan.

Pendidikan Anak usia dini juga diartikan sebagai jenjang pendidikan sebelum jenjang pendidikan dasar yang merupakan suatu pembinaan yang ditujukan bagi anak sejak lahir sampai dengan usia enam tahun yang dilakukan melalui pemberian rangsangan pendidikan untuk membantu pertumbuhan dan perkembangan jasmani dan rohani agar anak memiliki kesiapan dalam memasuki pendidikan lebih lanjut, yang diselenggarakan pada jalur formal, non formal dan informal.

. Pada anak usia taman kanak - kanak

kemampuan perkembangan akan sangat terlihat. Salah satu kemampuan anak yang berkembang dengan pesat adalah kemampuan fisik dan motoriknya.

Dalam kaitannya dengan perkembangan motorik anak, perkembangan motorik berhubungan dengan perkembangan kemampuan gerak anak . gerak merupakan unsur utama didalam pengembangan motorik anak. Oleh sebab itu, perkembangan kemampuan motorik anak akan dapat terlihat secara jelas melalui berbagai gerakan dan permainan yang dapat mereka lakukan. Jika anak banyak bergerak maka akan semakin banyak manfaat yang dapat diperoleh anak ketika anak makin terampil menguasai gerakan motoriknya. Selain kondisi badan semakin sehat karena banyak bergerak , anak juga akan menjadi lebih percaya diri dan mandiri. Anak menjadi semakin yakin dalam melakukan segala kegiatan yang dilakukannya.

Perkembangan motorik kasar berupa koordinasi gerakan tubuh seperti berlari, berjinjit, melompat, bergantung, melempar, menangkap dan sebagainya. Kegiatan tersebut diperlukan untuk meningkatkan kemampuan koordinasi gerakan motorik kasar.

Pada hakikatnya, semua anak memiliki keterampilan motorik kasar namun dalam tingkatan yang bervariasi. Sebagian anak memiliki motorik kasar yang baik, namun di sisi lain ada anak yang memiliki hambatan dalam perkembangan motorik kasar sehingga lebih lambat dari anak yang lainnya . hambatan perkembangan motorik kasar terbagi menjadi beberapa faktor seperti faktor penyakit,faktor lingkungan serta kepribadian. Faktor penyakit yang dapat memperlambat perkembangan motorik kasar salah satunya adalah spina bifina. Penyakit tersebut terjadi diakibatkan kelainan pertumbuhan sumsum tulang belakang yang mengakibatkan perkembangan motorik menjadi terhambat. Faktor lingkungan serta kepribadian juga dapat menghambat perkembangan motorik kasar. Anak yang tidak memiliki kesempatan untuk belajar seperti anak yang oleh orangtuanya sering digendong, sehingga tidak dibiarkan bebas untuk bergerak dapat mengalami keterlambatan dalam mencapai kemampuan motorik kasar.

Pada saat usia lima tahun pertama dalam kehidupan anak, motorik kasar inilah lebih dominan berkembang. Motorik kasar anak, berkembang sejalan dengan pertambahan usia dan kematangan saraf serta otot-otot anak. Menurut Sudjiono (2007, hlm .1 .5 ) menjelaskan mengenai efek penting dari peningkatan kemampuan motorik kasar Secara langsung pertumbuhan motorik kasar anak menentukan keterampilannya dalam bergerak. Sementara itu secara tidak langsung, pertumbuhan dan perkembangan kemampuan motorik kasar anak mempengaruhi cara anak memandang dirinya sendiri dan orang lain. Ini semua akan tercermin dari pola penyesuaian diri anak secara umum. Dari sini dapat 
disimpulkan bahwa keterampilan motorik kasar yang di dalamnya tercakup keterampilan gerak sangat diperlukan anak untuk bermain.

Salah satu permasalahan yang dihadapi pada proses pembelajaran di TK Pertiwi DWP adalah kondisi pembelajaran yang masih bersifat konvensional dan kurang menyentuh motorik kasar siswa itu sendiri. Hal ini teridentifikasi dari hasil observasi data anak secara langsung yang dibantu guru kelas kelompok B2. Pada saat observasi kegiatan pra siklus yang dilakukan kepada seluruh anak kelompok B2 TK Pertiwi DWP Kota Tasikmalaya keterampilan motorik kasarnya masih menunjukan dibawah kriteria ketuntasan minimal yang ditetapkan.hal tersebut terlihat dari belum mampunya anak melakukan kegiatan keterampilan motorik kasar dengan benar seperti dalam aspek gerak keterampilan lokomotor ketika anak berjalan masih banyak yang terlihat kaku, berlari tidak mencongkan badan kedepan, ketika meloncat sikap awal tidak membengkokan pinggul, masih belum bisa mengatur koordinasi gerakan tangan dan mata ketika melakukan kegiatan melempar, gerakan koordinasi menangkap masih lemah dan sebagainya.

Berdasarkan asumsi itulah yang kemudian mendorong Peneliti untuk memperbaiki proses pembelajaran dalam bidang pengembangan kemampuan keterampilan motorik kasar siswa kelompok B2 TK Pertiwi DWP Kota Tasikmalaya menggunakan metode yang mampu merangsang keterampilan motorik kasar siswa sehingga dapat memecahkan hambatan perkembangan dengan melakukan perbaikan pembelajaran khususnya bidang keterampilan motorik kasar siswa agar tidak berkelanjutan dan mengganggu perkembangan yang lainnya. Upaya ini tidak terlepas dari perbaikan paradigma guru sebagai penyelenggara pembelajaran di kelas terhadap proses pelaksanaan kegiatan pembelajaran.

Peneliti berupaya menemukan solusi pemecahan masalah tersebut melalui satu penelitian ilmiah yang berbentuk Penelitian Tindakan Kelas (PTK). Dalam hal ini PTK perlu dilaksanakan untuk meningkatkan proses dan praktis pembelajaran terutama dalam hal menanggulangi permasalahan pada bidang keterampilan motorik kasar anak usia dini pada siswa kelompok B2 TK Pertiwi DWP Kota Tasikmalaya.

Berikut merupakan rumusan masalah yang diadikan fokus penelitian :

1. Bagaimanakah kemampuan guru dalam perencanaan pembelajaran secara umum dengan permainan bola kecil di TK Pertiwi DWP Kota Tasikmalaya dalam upaya meningkatkan keterampilan motorik kasar anak usia dini kelompok B2 ?

2. Bagaimanakah kemampuan guru dalam pelaksanaan pembelajaran dengan permainan bola kecil di TK Pertiwi DWP Kota Tasikmalaya dalam upaya meningkatkan keterampilan motorik kasar anak usia dini kelompok B2 ?

3. Bagaimanakah peningkatan keterampilan motorik kasar anak usia dini Kelompok B2 di TK Pertiwi DWP Kota Tasikmalaya setelah penerapan pembelajaran dengan permainan bola kecil?

Adapun Tujuan Penelitian ini diantaranya :

1. Mengetahui peningkatkan kemampuan guru dalam perencanan pembelajaran melalui permainan bola kecil di TK Pertiwi DWP Kota Tasikmalaya untuk meningkatkan keterampilan motorik kasar anak kelompok B2 .

2. Mengetahui peningkatkan kemampuan guru dalam pelaksanaan pembelajaran melalui permainan bola kecil di TK Pertiwi DWP Kota Tasikmalaya untuk meningkatkan motorik kasar anak kelompok B2 .

3. Mengetahui peningkatan keterampilan motorik kasar anak usia dini kelompok B2 di TK Pertiwi DWP Kota Tasikmalaya sesudah diterapkannya permainan bola kecil. 


\section{TINJAUAN PUSTAKA}

Anak usia dini adalah sosok individu yang sedang menjalani proses perkembangan melalui pembinaan rangsangan pendidikan untuk membantu pertumbuhan dan perkembangan jasmani dan rohani bagi kehidupan selanjutnya yang berada pada rentang usia 0-8 tahun. Menurut WHO (2012, hlm 11) menjelaskan "Early childhood spans the pre-natal period to eight years of age It is the most intensive period of brain development throughout the lifespan and therefore is the most critical stage of human development". Masa kanak - kanak mencangkup usia pada saat lahir sampai usia delapan tahun merupakan periode perkembangan yang paling intensif sepanjang hidupnya dan periode paling kritis dalam masa kehidupan. Anak usia dini mengalami perkembangan dan pertumbuhan yang sangat cepat. Oleh karena itu, rangsangan yang diberikan seharusnya dapat menunjang seluruh aspek-aspek perkembangannya (Frida . 2016, hlm. 8).

\section{Konsep Permainan}

Permainan adalah hak asasi bagi anak usia dini yang memiliki nilai utama pada masa pra sekolah. Menurut Ingrid (2008) mengatakan “ Play, as well as learning, are natural components of children every lives " Bermain serta belajar bagi anak usia dini merupakan komponen keseharian yang tidak dapat dipisahkan.

Dunia anak adalah dunia bermain . dalam kehidupan anak - anak, sebagian besar waktunya dihabiskan dengan aktifitas bermain. Bermain dapat digunakan sebagai media untuk meningkatkan kemampuan tertentu pada anak.

Menurut Solehudin (1997, hlm. 80) permainan juga" mengembangkan keterampilan intelektual disaat anak terlibat dalam aktifitas - aktifitas yang menuntut fikirannya". Disaat anak bertukar pikiran melalui bahasa, melukis, membuat keputusan dan memecahkan masalah, dan disaat merasakan perbedaan antara fantasi dan realitas adalah contoh dari momen - momen bermain yang dapat berkontribusi terhadap pengembangan kemampuan intelektual anak.
Menurut Mulyadi ,( dalam Mariani, 2008 ) Bermain secara umum sering dikaitkan dengan kegiatan anak - anak yang dilakukan secara spontan. Terdapat 5 pengertian permainan adalah :

1.1 Sesuatu yang menyenangkan dan memiliki nilai intrinsik pada anak

1.2 Tidak memiliki nilai ekstrinsik, motivasinya lebih bersifat instrinsik

1.3 Bersifat spontan dan sukarela, tidak ada unsur keterpaksaan dan bebas dipilih oleh anak.

1.4 Melibatkan peran aktif keikutsertaan anak Memiliki hubungan sistematik yang khusus dengan sesuatu yang bukan bermain, seperti kreatifitas, pemecahan masalah, belajar bahasa, perkembangan sosial dan sebagainya.

\section{Pengertian dan Karakteristik Permainan Menggunakan Bola}

Sujiono (2007, hlm. 8.5), mengatakan bahwa bola merupakan mediapembelajaran yang akan membantu berbagai aspek perkembangan siswa, salah satunya adalah perkembangan motorik kasar siswa. Melalui pemanfaatan media bola akan mendorong kebutuhan siswa untuk secara aktif berinteraksi dan terlibat dengan lingkungan fisiknya. Pada saat yang sama dengan menggunakan media bola siswa berkesempatan untuk memperkaya gerakangerakannya, misalnya gerakan dengan sensori motor, tangan, kaki, kepala atau bagian tubuh yang lain yang melibatkan otot besar siswa, sehingga memungkinkan siswa secara penuh mampu mengembangkan kemampuan motorik kasar siswa.

Permainan yang menggunakan bola menurut pendapat dari Sujiono (2007, hlm 10.18), tidak memerlukan keterampilan tingkat tinggi, dan memungkinkan semua anak terlibat ke dalamnya, sehingga anak mampu merespon aktivitas dengan gembira, dapat digunakan secara individu maupun kelompok, dapat disesuaikan dengan tingkat perkembangan anak, dapat menyalurkan energi dan aspirasi anak. 


\section{Motorik Kasar}

Menurut Saputra dan Rudyanto (2005, hlm .117) motorik kasar adalah kemampuan anak beraktifitas dengan menggunakan otototot besarnya. Kemampuan ini bisa anak lakukan guna meningkatkan kualitas geraknya. Hal ini sesuai dengan pendapat Sujiono (2007, hlm. 1.17) bahwa motorik kasar adalah gerakan yang membutuhkan koordinasi sebagian besar bagian tubuh anak. Kemampuan menggunakan otot - otot besar atau kemampuan keterampilan motorik kasar bagi anak tergolong pada kemampuan gerak dasar. Menurut samsudin (2008, hlm. 8) kemampuan gerak dasar dibagi menjadi tiga kategori yaitu lokomotor, non lokomotor, dan manipulatif. Berikut gerakan - gerakan yang terdapat dalam setiap aspek keterampilan motorik kasar :

3.1 Keterampilan gerak dasar lokomotor merupakan gerakan yang dilakukan untuk memindahkan tubuh dari satu tempat ke tempat lainnya. Adapun kterampilan gerak dasar lokomotor diantaranya berjalan, berlari, meloncat.

3.2 Keterampilan gerak dasar non lokomotor merupakan gerakan yang dilakukan ditempat tanpa ruangan yang memadai. Adapun keterampilan gerak dasar non lokomotor diantaranya membungkuk dan memutar.

3.3 Keterampilan gerak dasar manipulatif adalah gerakan yang melibatkan pemberian gaya kepada objek - objek atau penerima gaya dai objek - objek. Adapun keterampilan gerak dasar manipulatif diantaranya melempar dan menangkap.

\section{Permainan bola Kecil untuk Meningkatkan Keterampilan Motorik Kasar Anak Usia Dini}

Tinjauan proses pembelajaran dengan permainan bola kecil sebagai upaya untuk meningkatkan motorik kasar anak. Permainan bola kecil adalah sebuah pendekatan pembelajaran yang digunakan sebagai pijakan bagi proses pembelajaran yang menekankan pada pentingnya perkembangan keterampilan motorik kasar anak. Namun peranan permainan bola kecil dalam membantu meningkatkan kemampuan motorik kasar anak dapat dilakukan melalui kegiatan yang diharapkan dapat mengembangkan tiga aspek gerak dasar motorik kasar diantaranya gerak dasar lokomotor, non lokomotor, dan manipulatif. Rokhayati, dkk ( 2016, hlm.57) dalam penelitiannya mengungkapkan bahwa kemampuan motorik dapat ditingkatkan melalui penerapan pendekatan pembelajaran taktis atau yang mengarah pada aktivitas jasmani secara aktif.

Adapun langkah - langkah kegiatan permainan bola kecil sebagai berikut :

\subsection{Permainan Bola Beranting}

Jumlah Pemain : setiap kelompok terdiri 3 - 6 orang

Usia : $5-6$ tahun

Tempat : Ruangan kelas yang lapang atau lapangan halaman sekolah

Alat yang digunakan : Bola plastik kecil, keranjang, dan peluit .

Tujuan : Meningkatkan Keterampilan gerak dasar Lokomotor (berlari) dan Non Lokomotor (memutar)

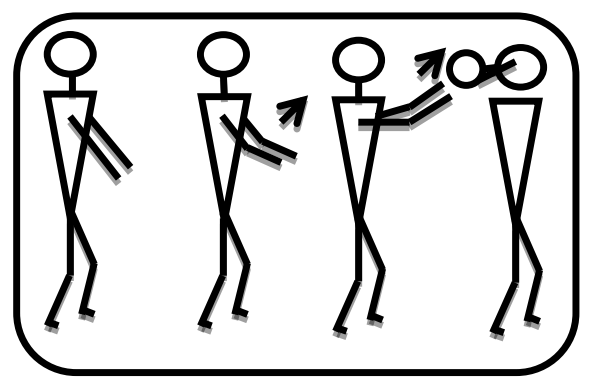

Gambar 1 : Cara melakukan permainan bola beranting

Langkah - langkah Permainan Bola Beranting Sebagai Berikut :

4.1.1 Seluruh anak dibagi menjadi beberapa kelompok dengan jumlah yang sama banyak. 
4.1.2 Lalu anak dibariskan berbanjar (berderet kebelakang), barisan menghadap satu arah dan jarak antar barisan kira - kira satu rentangan tangan.

4.1.3 Permainan dimulai pada saat guru membunyikan peluit lalu anak yang terdepan memegang bola memindahkan bola tersebut dengan cara kedua tangannya memegang bola dan memutarkan tangannya kebelakang melalui atas kepala dan memberikan bola tersebut kepada teman yang berada dibelakangnya.

4.1.4 Anak yang menerima bola akan memindahkan bola tersebut dengan cara yang sama .

4.1.5 Pada saat bola tersebut diterima oleh anak yang berdiri paling terakhir maka anak tersebut akan berlari kebarisan paling depan sambil mengatakan "Siap!", maka permainan dimulai kembali dari awal.

4.1.6 Untuk menentukan pemenangnya maka guru harus menentukan jumlah poin yang harus dicapai oleh setiap grup, poin disesuaikan dengan jumlah anak yang berada di grup misalnya guru menentukan jumlah 5 poin karena setiap grup jumlah anak ada 5 orang.

4.1.7 Setiap baris ketika menyelesaikan permainan atau dengan kata lain barisan tersebut mengatakan "Siap!" maka barisan tersebut mendapatkan 1 poin.

4.1.8 Barisan tercepat mendapatkan poin maksimal yang ditentukan oleh guru itulah pemenangnya.

4.1.9 Apabila ada kelompok yang jumlah anaknya tidak sama dengan kelompok lainnya maka poin yang dimainkan ditentukan dari kelompok yang jumlah anaknya paling sedikit

\subsection{Permainan lempar tangkap bola}

Jumlah pemain : 2 - 3 Kelompok
Usia : 5-6 tahun

Tempat : Ruang kelas yang lapang atau lapangan halaman sekolah Alat yang digunakan : Bola plastik kecil, keranjang, peluit

Tujuan : Meningkatkan keterampilan motorik gerak dasar Manipulatif ( melempar dan menagkap)

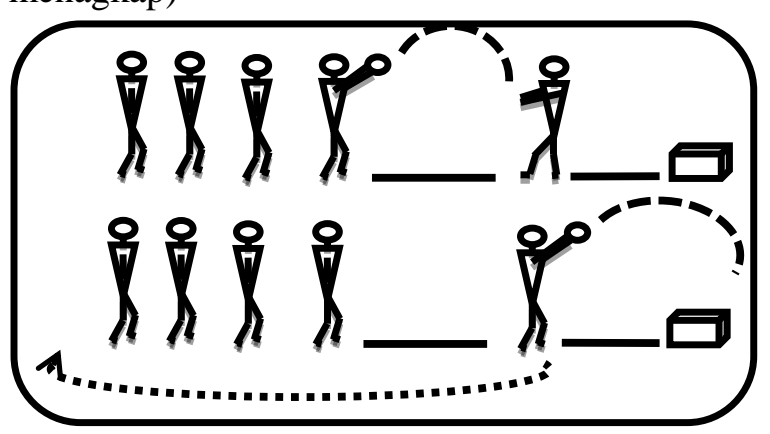

Langkah - langkah perrmainan Lempar tangkap bola sebagai berikut :

4.2.1 Setiap kelompok dibariskan berbanjar (berderet kebelakang) kemudian guru meminta anak nomor 1 yang berada dibarisan paling depan mengambil posisi terpisah dari barisan sejauh 2 meter .

4.2.2 Anak nomor 1 bertugas menangkap bola yang dilempakan oleh anak nomor 2.

4.2.3 Setelah anak nomor 1 menangkap bola yang dilempar dari anak nomor 2 , bola yang ditangkap tersebut dilempar ke keranjang yang sudah disediakan oleh guru dengan jarak sejauh 1 meter.

4.2.4 Permainan dimulai ketika guru memberikan tanda ( meniup peluit), Anak nomor 2 langsung melemparkan bola ke anak nomor 1 kemudian anak nomor 1 melemparkan bola ke keranjang

4.2.5 Kemudian anak nomor 1 kembali ke barisan diposisi paling belakang, sedangkan anak nomor 2 menggantikan posisi anak nomor 1 sebagai pelempar.

4.2.6 Posisi Anak nomor 2 sebagai pelempar digantikan oleh anak nomor 3 dan melakukan tugasnya seperti tadi yang dilakukan anak nomor 2 . 
4.2.7 Seterusnya di ikuti oleh anak lainnya sampai semua bola tersebut dapat dimasukan kedalam keranjang

4.2.8 Apabila ada bola yang dilempar tidak masuk kedalam keranjang, maka harus diulang kembali dan anak tersebut kembali kebarisan belakang.

4.2.9 Pemenang dalam permainan ini ditentukan oleh kelompok yang paling cepat memasukan semua bola kedalam keranjang.

\subsection{Permainan bolak - balik memindahkan bola}

Jumlah pemain $\quad: 2-3$ kelompok

Usia : $5-6$ tahun

Tempat : Ruang kelas yang lapang atau lapangan halaman sekolah

Alat yang digunakan : Bola plastik kecil, keranjang, lakban dan kerucut.

Tujuan : Meningkatkan keterampilan motorik gerak dasar Lokomotor ( berjalan dan meloncat ) dan Non Lokomotor ( membungkuk).

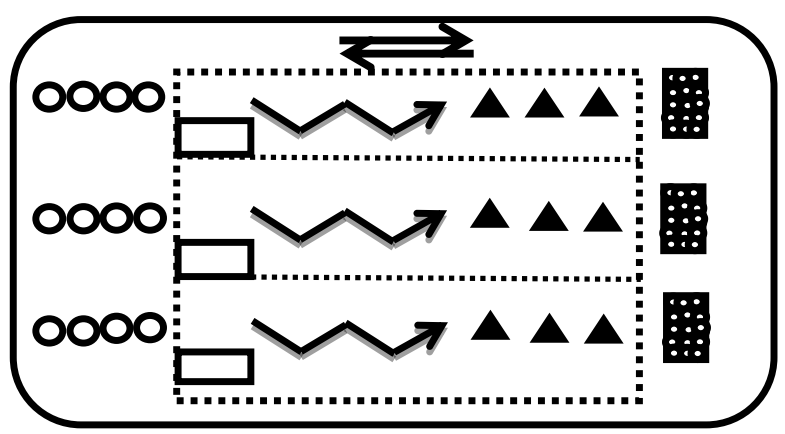

Gambar 3: Denah Permainan Bolak - Balik Memindahkan Bola

Langkah - Langkah Permainan Bolak - Balik Memindahkan Bola :

4.3.1 Guru membagi anak - anak menjadi 2 - 3 kelompok barisan berbanjar (berderet kebelakang)

4.3.2 Masing - masing barisan menempati jalur lintasan sejauh 5 meter yang sudah disediakan

4.3.3 Didalam lintasan anak harus melewati rintangan yaitu berjalan diatas garis yang diletakan dilantai secara zigzag (berjalan secara berbelok - belok kekanan dan kekiri) kemudian anak meloncat untuk melewati kerucut yang menjadi rintangan

4.3.4 Di luar batas akhir guru menempatkan 5 - 10 buah bola yang disimpan didalam wadah.

4.3.5 Setelah mendengar aba - aba dari guru ( meniup peluit) maka anak nomor 1 yang berada digaris awal barisan paling depan berjalan melewati rintangan.

4.3.6 Rintangan pertama yang harus dilewati yaitu anak berjalan diatas tali yang diletakan dilantai secara zigzag

4.3.7 Setelah itu anak harus meloncat untuk melewati kerucut

4.3.8 Saat sampai di luar batas akhir anak membungkuk untuk mengambil 1buah bola.

4.3.9 Kemudian anak kembali kegaris awal dengan melewati rintangan yang sudah dilewati kemudian bola tersebut dikumpulkan dan anak tersebut berbaris paling belakang.

4.3.10 Dilanjutkan dengan anak nomor 2 melewati rintangan, mengambil bola , kembali kegaris awal dan seterusnya diikuti oleh anak lainnya.

4.3.11 Pemenang ditentukan dari kelompok yang sudah memindahkan semua bola paling cepat.

\section{METODE PENELITIAN}

Penelitian ini menggunakan penelitian tindakan kelas atau sering disebut dengan classroom action reasearch dalam bahasa inggris yang selanjutnya disebut PTK yang bersifat deskriptif kualitatif.

Subjek penelitian ini adalah seluruh siswa kelompok B2 (5 - 6 Tahun ) di TK Pertiwi DWP Kota Tasikmalaya sebanyak 14 anak yang terdiri dari 10 anak perempuan dan 4 anak laki - laki. Selain anak, guru juga termasuk subjek penelitian sekaligus observer.

\section{Teknik Pengumpulan Data}




\subsection{Lembar observasi}

Dilihat dari persiapan maupun pelaksanaannya observasi pada penelitian ini lebih bersifat sistematis, sebab pada penelitian ini metode observasi yang digunakan harus dipersiapkan serta direncanakan terlebih dahulu segala sesuatu yang dibutuhkan baik mengenai aspek-aspek yang diamati, waktu observasi, maupun alat yang digunakan pada saat kegiatan pembelajaran melalui permainan bola kecil ketika sedang berlangsung, yaitu dari awal sampai akhir. Dalam hal ini peneliti menggunakan observasi partisipatif, dimana peneliti ikut serta mengamati aktivitas peserta didik selama proses kegiatan berlangsung.

\subsection{Catatan Lapangan}

Catatan lapangan adalah catatan yang dikumpulkan oleh peneliti untuk merekam kejadian - kejadian diluar perencanaan yang sudah disusun sedemikian rupa oleh peneliti sehingga menjadi acuan untuk peneliti agar bisa menjadi bahan renungan peneliti di siklus seklanjutnya.

\section{Teknik Analisis Data}

Teknik analisis data dalam penelitian ini terbagi menjadi 2 . hal itu untuk mengetahui kemampuan guru dalam merencanakan dan melaksanakan permainan bola kecil untuk meningkatkan keterampilan motorik kasar anak dan penilaian keterampilan motorik kasar anak melalui permainan bola kecil anak.

Untuk Kriteria penilaian Guru dalam perencanaan dan pelaksanaan pembelajaran permainan bola kecil untuk meningkatkan keterampilan motorik kasar anak usia dini dapat dilihat di tabel dibawah ini menurut Aqib (2009, hlm 270) :
Tabel 1 . Kriteria Penilaian Guru dalam perencanaan dan pelaksanaan pembelajaran permainan bola kecil untuk meningkatkan keterampilan motorik kasar anak usia dini.

\begin{tabular}{cccc}
\hline No & $\begin{array}{c}\text { Kriteria } \\
\text { Penilaian }\end{array}$ & Nilai & Persentase \\
\hline 1 & Sangat Baik & 4,00 & $100 \%-90 \%$ \\
& & - \\
& 3,00 \\
\hline 2 & Baik & 2,99 & $89 \%-70 \%$ \\
& & - \\
& & 2,00 \\
\hline 3 & Cukup & 1,99 & $69 \%-50 \%$ \\
& & - & \\
& & 1,00 & \\
\hline 4 & Kurang & 0,99 & $49 \%-30 \%$ \\
& & - \\
& & 0,00 \\
\hline
\end{tabular}

Peneliti menggunakan presentase statistik sederhana untuk mengetahui kemampuan permainan bola kecil untuk meningkatkan keterampilan motorik kasar anak usia dini .Untuk melihat kriteria penilaian keterampilan motoik kasar anak usia dini dapat dilihat di tabel dibawah ini :

Tabel 2 . Kriteria Penilaian untuk Pencapaian Keterampilan Motorik Kasar Anak Usia Dini Melalui Permainan Bola Kecil

\begin{tabular}{ccc}
\hline No & Kriteria Penilaian & Simbol \\
\hline 1 & $\begin{array}{c}\text { Berkembang Sangat } \\
\text { Baik }\end{array}$ & BSB \\
\hline 2 & $\begin{array}{c}\text { Berkembang Sesuai } \\
\text { Harapan }\end{array}$ & BSH \\
\hline 3 & Mulai Berkembang & MB \\
\hline 4 & Belum Berkembang & BB \\
\hline
\end{tabular}

Data observasi aktivitas guru dalam merencakan, melaksanakan kegiatan pembelajaran dan aktifitas anak selama kegiatan belajar mengajar berlangsung dianalisis dengan menggunakan penghitungan persentase. Penghitungannya 
sebagai berikut : Analisis data di bawah ini, diadaptasi dari Aqib (2014, hlm 41)

$$
P=\frac{\mathrm{f}}{N} \times 100 \%
$$

Keterangan :

$\mathrm{P}=$ Persentase yang dicari

$\mathrm{F}=$ Frekuensi atau banyaknya deskriptor kemampuan guru / anak yang muncul

$\mathrm{N}=$ Jumlah aktivitas keseluruhan

Tabel 3. Skor Penilaian Anak untuk Pencapaian Deskriptor Keterampilan Motorik Kasar Anak Usia Dini Melalui Permainan Bola Kecil

\begin{tabular}{ccc}
\hline No & $\begin{array}{c}\text { Kriteria } \\
\text { Penilaian }\end{array}$ & $\begin{array}{c}\text { Pencapaian } \\
\text { Deskriptor }\end{array}$ \\
\hline 1 & $\begin{array}{c}\text { Berkembang } \\
\text { Sangat Baik }\end{array}$ & 3 \\
\hline 2 & $\begin{array}{c}\text { Berkembang } \\
\text { Sesuai Harapan }\end{array}$ & 2 \\
\hline 3 & $\begin{array}{c}\text { Mulai } \\
\text { Berkembang }\end{array}$ & 1 \\
\hline 4 & $\begin{array}{c}\text { Belum } \\
\text { Berkembang }\end{array}$ \\
\hline
\end{tabular}

Kriteria penilaian Berkembang Sangat

Baik telah mencapai 3 deskriptor, kriteria penilaian Berkembang Sesuai Harapan telah mencapai 2 deskriptor, kriteria penilaian Mulai Berkembang telah mencapai 1 deskriptor, dan kriteria penilaian Belum Berkembang telah mencapai 0 deskriptor / belum mencapai deskriptor satu pun.

\section{HASIL DAN PEMBAHASAN}

Setelah menyelesaikan tiga siklus, peneliti dan observer melakukan refleksi akhir untuk mengevaluasi keseluruhan tindakan selama penelitian berlangsung, mulai dari siklus I samapai siklus III. Peneliti dan observer sepakat bahwa permainan bola kecil untuk meningkatkan keterampilan motorik kasar anak usia dini pada kelompok B2 TK Pertiwi DWP Kota Tasikmalaya dapat dilaksanakan dengan baik. hal ini ditunjukan dengan adanya peningkatan dari hasil akhir data setiap siklusnya. Berikut peneliti akan memaparkan hasil keseluruhan siklus :

\section{Perubahan Kemampuan Guru Menyusun Perencanaan dan Pelaksanaan Pembelajaran secara Keseluruhan}

Kemampuan guru dalam perencanaan dan pelaksanaan keseluruhan pembelajaran sudah dinyatakan berhasil apabila sudah melebihi nilai minimal dengan kesepakatan bersama observer yaitu sebesar $75 \%$ dengan kriteria baik . Pada perencanaan Siklus I diketahui nilai sebesar 68,60\% dengan kriteria cukup dan pelaksanaan Siklus I diketahui sebesar $71 \%$ dengan kriteria baik. Kemudian Peneliti melakukan perbaikan dalam perencanaan dan pelaksanaan pembelajaran siklus I dengan melakukan refleksi bersama observer dan dosen pembimbing sehingga pada siklus II diharapkan terjadi peningkatan. Pada Perencanaan Siklus II diketahui nilai sebesar 72,6 \% dengan kriteria baik dan pada pelaksanaan siklus II diketahui nilai sebesar $81 \%$. Pada siklus II ini untuk nilai pelaksanaan sudah nilai minimal namun untuk perencanaan belum melebihi nilai minimal sehingga harus dilakukan refleksi kembali bersama observer dan diharapkan ada peningkatan yang lebih optima di siklus III. Pada siklus III diketahui nilai perencanaan pembelajaran mencapai $81 \%$ dengan kriteria baik dan Pelaksanaan mencapai 91,5\% dengan kriteria sangat baik sehingga peneliti dan observer sepakat untuk menghentikan penelitian di siklus III karena sudah melebihi batas minimal penilaian dan pembelajaran dapat disimpulkan berhasil.

Untuk peningkatan perencanaan dari siklus I dampai siklus III yaitu sebesar 12,40 $\%$ dan peningkatan pelaksanaan pembelajaran dari siklus I sampai siklus III yaitu sebesar 20,5\%. Untuk lebih jelasnya dapat dilihat tabel 4.29 berikut ini : 
Tabel 4.29 . Perubahan Skor Kemampuan

Guru melakukan Perencanaan dan

Pelaksanaan Pembelajaran Siklus I - III

\begin{tabular}{cccc}
\hline No & Siklus & Perencanaan & Pelaksanaan \\
\hline 1 & Siklus I & $68,60 \%$ & $71 \%$ \\
\hline 2 & Siklus II & $72.6 \%$ & $81 \%$ \\
\hline 3 & Siklus & $81 \%$ & $91,5 \%$ \\
III & & \\
\hline $\begin{array}{l}\text { Peningkatan } \\
\text { Kemampuan } \\
\text { Guru } \\
\text { melakukan }\end{array}$ & & \\
Perencanaan & $12,40 \%$ & $20,5 \%$ \\
dan & & \\
Pelaksanaan & & \\
Siklus I - & & \\
Siklus III & & \\
\hline
\end{tabular}

2. Perubahan Penilaian Pelaksanaan Permainan Bola Kecil

Pembahasan perubahan penilaian pelaksanaan permainan bola kecil yaitu membahas tentang evaluasi yang dilakukan peneliti setiap siklusnya sesuai dengan lembar observasi pelaksanaan permainan bola kecil sehingga dapat diinformasikan kepada peneliti oleh observer apakah permainan bola kecil tersebut sudah optimal atau belum optimal. Sehingga dapat dilakukan perbaikan dan penyesuaian yang positif sehingga berimbas kepada peningkatan keterampilan motorik kasar anak usia dini pada kelompok B2 TK Pertiwi DWP kota Tasikmalaya yang diharapkan. Adapun penjelasannya berdasarkan tabel perubahan pelaksanaan permainan bola kecil dari siklus I sampai siklus III dibawah ini.
Tabel 4.30 . Perubahan Skor Penilaian Pelaksanaan Permainan Bola Kecil Siklus IIII

\begin{tabular}{cccc}
\hline No & Siklus & $\begin{array}{c}\text { Penilaian } \\
\text { Pelaksanaan } \\
\text { Permainan } \\
\text { Bola kecil }\end{array}$ & Peningkatan \\
\cline { 1 - 2 } 1 & $\begin{array}{c}\text { Siklus } \\
\text { I }\end{array}$ & $58,33 \%$ & \\
\cline { 1 - 2 } 2 & $\begin{array}{c}\text { Siklus } \\
\text { II }\end{array}$ & $75 \%$ & \\
& Siklus & $83 \%$ & \\
\hline 3 & III & & \\
& & &
\end{tabular}

Dari tabel 4.30 dapat diinformasikan bahwa untu penilaian pelaksanaan permainan bola kecil siklus I mendapatkan nilai sebesar 58,33 $\%$ dengan kriteia cukup. Penyebabnya yaitu pada pelaksanaan permainan bola kecil ditemukan berbagai masalah pada siklus I sehingga peneliti melakukan refleksi memaparkan semua masalah yang dihadapi pada siklus I dengan dosen pembimbing. Setelah refleksi maka peneliti melanjutkan ke siklus II. Pada penilaian pelaksanaan permainan bola kecil siklus II terjadi peningkatan penilaian yang lumayan besar yaitu sebesar $75 \%$ denga kriteria cukup. Hasil tersebut dipengaruhi oleh refleksi yang dilakukan pada siklus I. Dikarenakan penilaian baru mencapai batas minimal yaitu $75 \%$ maka peneliti melanjutkan pelaksanaan permainan ke siklus III agar mendapatkan hasil yang optimal. Pada siklus III pelaksanaan permainan bola kecil mendapatkan nilai sebesar $83 \%$ dengan kriteria baik. dari hasil tersebut peneliti mencermati dari siklus I sampai siklus III telah terjadi peningkatan yang memuaskan. 
3. Perubahan Peningkatan Keterampilan Motorik Kasar anak usia dini Kelompok B2 TK Pertiwi DWP Kota Tasikmalaya dari Pra Tindakan Siklus III

Peningkatan keterampilan motorik kasar anak usia dini telah terjadi peningkatan setiap siklusnya, hal ini menunjukan bahwa permainan bola kecil memberikan dampak positif pada anak kelompok B2 TK Pertiwi DWP Kota Tasikmalaya.

Data peningkatan keterampilan motorik kasar anak usia dini dapat terlihat di tabel berikut ini :

Tabel 4.31 . Perubahan Keterampilan Motorik Kasar Anak Usia Dini Pra Tindakan - Siklus III

\begin{tabular}{|c|c|c|c|c|c|}
\hline \multirow{4}{*}{ Aspek } & \multirow{4}{*}{ Indkator } & \multicolumn{4}{|c|}{$\begin{array}{c}\text { Jumlah Pencapaian Anak } \\
\text { dengan kriteria BSB dan } \\
\text { BSH }\end{array}$} \\
\hline & & Pra & Sikl & Sikl & $\overline{\text { Sikl }}$ \\
\hline & & Tinda & us I & us & us \\
\hline & & kan & & II & III \\
\hline \multirow{2}{*}{ Aspek } & Berlari & 1 & 5 & 8 & 12 \\
\hline & Berjalan & 1 & 3 & 6 & 11 \\
\hline \multirow{2}{*}{$\begin{array}{l}\text { lokom } \\
\text { otor }\end{array}$} & Melonca & 2 & 4 & 7 & 10 \\
\hline & $\mathrm{t}$ & & & & \\
\hline \multirow{5}{*}{$\begin{array}{l}\text { Aspek } \\
\text { Gerak } \\
\text { Non } \\
\text { Lokom } \\
\text { otor }\end{array}$} & Membun & 2 & 4 & 8 & 11 \\
\hline & gkuk & & & & \\
\hline & Memuta & 1 & 5 & 6 & 11 \\
\hline & $\mathrm{r}$ & & & & \\
\hline & & & & & \\
\hline \multirow{4}{*}{$\begin{array}{l}\text { Aspek } \\
\text { Gerak } \\
\text { Manip } \\
\text { ulatif }\end{array}$} & Melemp & 2 & 4 & 7 & 12 \\
\hline & ar & & & & \\
\hline & Menang & 0 & 4 & 8 & 10 \\
\hline & kap & & & & \\
\hline
\end{tabular}
menjelaskan bahwa jumlah anak yang sudah mencapai kriteria ketuntasan minimal dengan kriteria (BSH dan BSB). Untuk aspek gerak lokomotor terdiri dari indikator berlari, berjalan dan meloncat.

Pada indikator berlari, anak yang sudah mencapai indikator keberhasilan pada Pra Tindakan sebanyak 1 anak $(7,14 \%)$, siklus I sebanyak 5 anak (35,71\%), siklus II sebanyak 8 anak $(57,14 \%)$ dan siklus III sebanyak 12 anak $(85,71 \%)$. Pada siklus III indikator berlari sudah melebihi indikator keberhasilan jumlah anak yang mencapai BSH dan BSB sebesar $85,71 \%$.

Pada indikator berjalan, anak yang sudah mencapai indikator keberhasilan pada Pra Tindakan sebanyak 1 anak $(7,14 \%)$, siklus I sebanyak 3 anak (21,42\%), siklus II sebanyak 6 anak $(42,85 \%)$ dan siklus III sebanyak 11 anak $(78,57 \%)$. Pada siklus III indikator berjalan sudah melebihi indikator keberhasilan jumlah anak yang mencapai BSH dan BSB sebesar 78,57 \%.

Pada indikator meloncat, anak yang sudah mencapai indikator keberhasilan pada Pra Tindakan sebanyak 2 anak (14,28\%), siklus I sebanyak 4 anak $(28,57 \%)$, siklus II sebanyak 7 anak (50 \%) dan siklus III sebanyak 10 anak (71,42\%). Pada siklus III indikator meloncat sudah melebihi indikator keberhasilan jumlah anak yang mencapai BSH dan BSB sebesar 71,42\%.

Selanjutnya untuk aspek gerak non lokomotor terdapat dua inikator yaitu membungkuk dan memutar.

Pada indikator membungkuk, anak yang sudah mencapai indikator keberhasilan pada Pra Tindakan sebanyak 2 anak (14,28\%), siklus I sebanyak 4 anak $(28,57 \%)$, siklus II sebanyak 8 anak $(57,14 \%)$ dan siklus III sebanyak 11 anak $(78,57 \%)$. Pada siklus III indikator membungkuk sudah melebihi indikator keberhasilan jumlah anak yang mencapai BSH dan BSB sebesar 78,57\%.

Pada indikator memutar, anak yang sudah mencapai indikator keberhasilan pada Pra Tindakan sebanyak 1 anak $(7,14 \%)$, siklus I sebanyak 5 anak $(35,71 \%)$, siklus II sebanyak 6 anak $(42,85 \%)$ dan siklus III sebanyak 11 anak $(78,57 \%)$. Pada siklus III indikator memutar sudah melebihi indikator keberhasilan jumlah anak yang mencapai BSH dan BSB sebesar 78,57\%.

Kemudian untuk aspek manipulatif terdiri dari dua indikator yaitu melempar dan menangkap.

Pada indikator melempar, anak yang sudah mencapai indikator keberhasilan pada Pra Tindakan sebanyak 2 anak (14,28\%), 
siklus I sebanyak 4 anak $(28,57 \%)$, siklus II sebanyak 7 anak (50\%) dan siklus III sebanyak 12 anak (85,71\%). Pada siklus III indikator melempar sudah melebihi indikator keberhasilan jumlah anak yang mencapai BSH dan BSB sebesar 85,71\%.

Pada indikator menangkap, anak yang sudah mencapai indikator keberhasilan pada Pra Tindakan sebanyak 0 anak $(0 \%)$, siklus I sebanyak 4 anak (28,57\%), siklus II sebanyak 8 anak $(57,14 \%)$ dan siklus III sebanyak 10 anak $(71,42 \%)$. Pada siklus III indikator menangkap sudah melebihi indikator keberhasilan jumlah anak yang mencapai BSH dan BSB sebesar 71,42\%.

Dengan mencermati setiap indikator keterampilan motorik kasar setiap aspeknya, maka diperoleh informasi bahwa permainan bola kecil dapat meningkatkan keterampilan motorik kasar anak usia dini pada kelompok B2 TK Pertiwi DWP Kota Tasikmalaya. Hal ini dibuktikan dengan setiap indikator pencapaian penilaian anak dari Pra Tindakan sampai siklus III telah melebihi indikator keberhasilan penelitian ini dengan hasil memuaskan.

\section{KESIMPULAN}

Berdasarkan hasil penelitian yang telah dilakukan di TK Pertiwi DWP Kota Tasikmalaya pada kelompok B2 terkait peningkatan keterampilan motorik kasar anak usia dini . maka peneliti dapat mengambil simpulan sebagai berikut:

1. Peningkatan kemampuan guru dalam perencanaan pembelajaran secara umum dengan permainan bola kecil untuk meningkatkan keterampilan motorik kasar anak pada kelompok B2 di TK Pertiwi DWP Kota Tasikmalaya mengalami peningkatan yang berarti. Hal tersebut dapat terlihat dari peningkatan dari setiap tindakan yang dilakukan oleh peneliti dari siklus I sampai siklus III. Pada siklus I mendapatkan skor dengan kriteria cukup kemudian pada siklus II dan III meningkat dengan mendapatkan skor yang sama yaitu kriteria baik.

2. Peningkatan kemampuan guru dalam pelaksanaan terbagi menjadi dua yaitu pelaksanaan pembelajaran secara umum dan pelaksanaan permainan bola kecil. Untuk peningkatan kemampuan guru dalam pelaksanaan permainan secara umum pada siklus I dan II mendapatkan skor dengan kriteria Baik kemudian pada siklus III meningkat menjadi kriteria sangat baik. kemudian untuk Pelaksanaan Pemainan Bola Kecil pada siklus I mendapatkan skor dengan kriteria cukup dan pada siklus II dan III meningkat dengan kriteria skor baik.

3. Peningkatan Pencapaian Anak dalam Keterampilan Motorik Kasar Anak Usia Dini Kelompok B2 TK Pertiwi DWP Kota Tasikmalaya terjadi peningkatan yang signifikan untuk setiap indikatornya dari mulai pra tindakan sampai siklus III . hal tersebut memberikan kesimpulan bahwa permainan bola kecil dapat meningkatkan keterampilan motorik kasar anak usia dini.

\section{DAFTAR PUSTAKA}

Aqib, Z. (2009). Penelitian Tindakan Kelas. Bandung: Yrama Widya.

Aqib, Z.Dkk. (2014). Penelitian Tindakan Kelas untuk Guru SD, SLB dan TK. Bandung: Yrama Widya.

Ingrid.S, M.A.C .(2008). The Playing Learning Child : Toward a Pedagogy of early childhood, 52(6). hlm 623.

Mariani, A.(2008, 12 Desember). Bermain dan Kreativitas pada Anak Usia Dini. [Online]. Diakses dari : $\mathrm{http} / /$ deviarimariani.wordpress.com.

Rokhayati, A., Nur, L., Elan., dan Gandana, G.(2016, September). Implementasi Pendekatan Taktis dalam Pembelajaran Pendidikan Jasmani Terhadap Motivasi, Kebugaran Jasmani, dan 
Kemampuan Motorik. Jurnal Pendidikan Jasmani dan Olahraga, Volume 1, Nomor 2, hlm 57-67.

Samsudin.(2008). Pengembangan motorik di Taman Kanak - kanak. Jakarta: Universitas Negeri Jakarta.

Saputra, M., Y. R.(2005). Pembelajaran Kooperatif untuk Meningkatkan Keterampilan Motorik Anak TK. Jakarta:Depdiknas.

Solehuddin, M .(1997). Konsep Dasar Pendidikan Prasekolah. Bandung; Fakultas Ilmu Pendidikan IKIP Bandung.

Sujiono, B. (2007). Metode Pengembangan Fisik. UniversitasTerbuka: Jakarta.

Sujiono, B. (2009). Konsep Dasar Pendidikan Anak Usia Dini. Jakarta: PT Indeks.

World Health Organization.(2012). Early childhood depelopment and disabilities. Malta. WHO and UNICEF 